TURIZAM

Volume 21, Issue 4

$172-184(2017)$

ORIGINAL

SCIENTIFIC PAPER

\title{
International Hotel Chains in Montenegro - Focus on Ramada Hotel Podgorica
}

\author{
Silvana Đurašević $\mathrm{A}^{*}$, Andrea Kavarić ${ }^{A}$ \\ Received: September 2017 | Accepted: December 2017 \\ DOI: 10.5937/turizam21-16721
}

\begin{abstract}
International hotel chains have been present in the Montenegrin market for the past 13 years, but their influence on hospitality industry, as a branch, has only been strong in the last five years. The first hotel, which belongs to a hotel chain, came in 2004 by opening the Iberostar Bellevue Hotel in Becici. Today, there are eight branded hotels in Montenegro. The purpose of the research in this paper will be the contemporary trends in hospitality industry and their impact on the Montenegrin market. Research results suggest that although the share of branded hotels is small, the brand's strength makes them dominant on the market and allows them the position of the demand generator and partially the offer creator. Furthermore, new trends have brought changes in the quality of service, application of standards, the creation of hotel products, sales and other essential issues for the hotel operation. A special review was given to the Ramada Hotel Podgorica, whose appearance on the capital city market strengthened and facilitated the opening of new branded hotels, such as Hilton Podgorica and Center Ville Hotel. Also, Ramada's business analysis has helped significantly in highlighting the contribution of this and other branded hotels to the establishment of a modern hotel business in Montenegro.
\end{abstract}

Keywords: International hotel chains, new trends, Ramada, Montenegro

\section{Introduction}

The entry of international hotel chains into the Montenegrin market has brought significant novelties into the hotel business, as well as all other subjects in the value chain at the destination. The business operations of hotel companies and their position in the tourism market are directly dependent on trends in international tourism, i.e. they are conditioned by the changes in the scope and structure of tourist demand on one hand, and technological development on the other (Barjaktarović, Pindžo, 2016). Changes that have occurred in the market can be seen from two aspects: external and internal or macro and micro levels, depending on the perspective of the process perceived. Or as they say (McCarthy, 1975; Porter, 2008), influencing factors can be viewed from an external point of view, and in this case they are referred to as macro-

A Faculty of tourism, University Mediterranean Podgorica, Josipa Broza Tita bb, 81000 Podgorica, Montenegro

* Corresponding author: silvanadj@t-com.me 
economic factors, or when viewed from the internal side of the company, they are defined as so-called micro-economic factors (Mussing, 2007). Both factors are in interaction and are subject to changes in the market.

Changes made on a macro plan have affected the tourist market of Montenegro and all its participants. The changes in the micro-plan have been created in business units (hotels) and they are a novelty in running the concept of business and business philosophy in general. The concept of the trend in all definitions includes the word change as a key determinant, and in Collins dictionary (2017), it is defined as "a change or development towards something new or different".

Change of the ownership structure in hospitality industry of Montenegro caused the collapse of large state-owned companies and establishment of smaller private hotels that found it difficult to follow new trends growing in hospitality industry worldwide. Globalization and internationalization have led to a high concentration in hospitality industry and tourism in general, both horizontal and vertical, the application of new information technologies, introduction of contemporary quality standards, new management concepts, expansion to new markets, which could not be fought by such fragmented hotel structure. The arrival of new investments and international hotel chains has initiated changes both in operation of smaller hotels and other participants in the destination, who have to adapt to new trends and sophisticated consumer demands in order to remain in the market.

The most significant changes in hotel industry took place directly upon the emergence of Ramada brand on the Montenegrin market. Hotel Ramada Podgorica was opened in 2012 and is the first branded foreign-owned hotel. Additionally, the hotel is a pioneer in using the services of management companies, thus, since the opening to October 2016 the hotel was managed by a Swiss company Sophos Hotels. This hotel has strongly influenced the congress tourism development in Montenegro, outsourcing in hospitality industry, staff training and development, socially responsible business and other segments of hospitality business that shall be discussed further in the paper.

\section{Methods and data}

Primary and secondary data were used for the research purposes. Secondary research is based on the existing bibliographic sources. The primary data was obtained by an interview method with partially prepared open type questions. The focus is on the attitudes of top management in the selected hotels (Ramada, Hilton and Regent), which have been processed by scientific methods of analysis, synthesis, deduction and induction, with the aim of identifying current trends in tourism. Questions in the questionnaire referred to the attitudes of management on the degree of congress tourism development in Montenegro, cooperation with tourist agencies, outsourcing, relations with market competitors, implementation of standards, employees, use of PMS and CRS ${ }^{1}$, environmental protection and social responsible business. Hotels whose mandate is included in the survey are carefully selected according to their market position and impact on the market as a whole. All selected hotels have a significant number of accommodation units and a specific business enabling them to be the generators of new trends, which will be further discussed. Due to the high level of hotel management occupancy, the second part of the survey used a telephone interview method with a semi-structured open questionnaire

PMS - Property Management System; CRS - Central Reservation System 
technique, where all eight branded hotels in Montenegro were interviewed. The results of this research, which addressed the same questions as in the interviews questionnaire, for a better overview and the effort to develop the framework of hotel development trends, are presented in tabular form. By conducting a telephone questionnaire $100 \%$ sample was processed. Personal interviews were conducted in three hotels, making a sample of $37.5 \%$.

\section{International hotel chains as a contemporary trend}

The emergence of $\mathrm{IHCs}^{2}$ in the world is related to the names of the masters of hospitality industry, Cesar Ritz and Conrad Hilton and the beginning of the 2oth century. The IHC's business concept today is based on the original business philosophy that implied a strong horizontal linkage and the establishment of unique standards. Hotel chains are defined as: "an enterprise that administrates, through a unique management, a number of hotels located in different areas. They can be total or partial owners of the hotel and they manage their administration, marketing and promotion "(Hotels' 325,2008 ).

IHCs were created under the influence of external and internal factors. The external factors of hotel chains include:

- Expansion of demand for hotel services and

- The need to accelerate the economic development of particular regions (Čačić, 2010).

The internal factors of establishment of hotel chains include the need to diversify the offer. Numerous brands that nowadays make portfolios of large hotel chains have been created for the need to diversify the offer within hotel chains. More sophisticated consumers and the emergence of a growing number of segments and sub segments in the tourist market have caused the need to harmonize the offer with high requirements of the demand and the emergence of new brands within the existing hotel companies. The internationalization of hotel and motel chains started in the 1950 os and 1960 os with companies such as Hilton, Holiday Inn, Marriott and Ramada Inn (Alon et al., 2012).

The dynamics of tourist movements since 1950 with predictions until 2030 is shown in Figure 1.

The chart clearly shows a large expansion of tourist movements over the last 60 years, which inevitably influenced the development of the hospitality industry as a key branch of the tourist system and enabled the emergence of IHC. The period of the ' 50 s and the ' 60 os of the past century is characterized by the imbalance in the dynamics of the demand and supply growth. The growth in demand was significantly more dynamic than the growth of supply, and the market gap between these two segments was utilized by hotel chains. In the years to come, the tourism demand has grown significantly under the influence of the following factors:

- growth in household income,

- increases in expenditures for supplementary needs of the population,

- increase in free time,

- international stability and security,

- reduction of administrative constraints in international travel,

- freer relations in international exchange markets,

- expansion of fast and efficient public transport combined with increased private transport (Lockwood, Medlik, 2001).

2 IHC - International Hotel Chains 


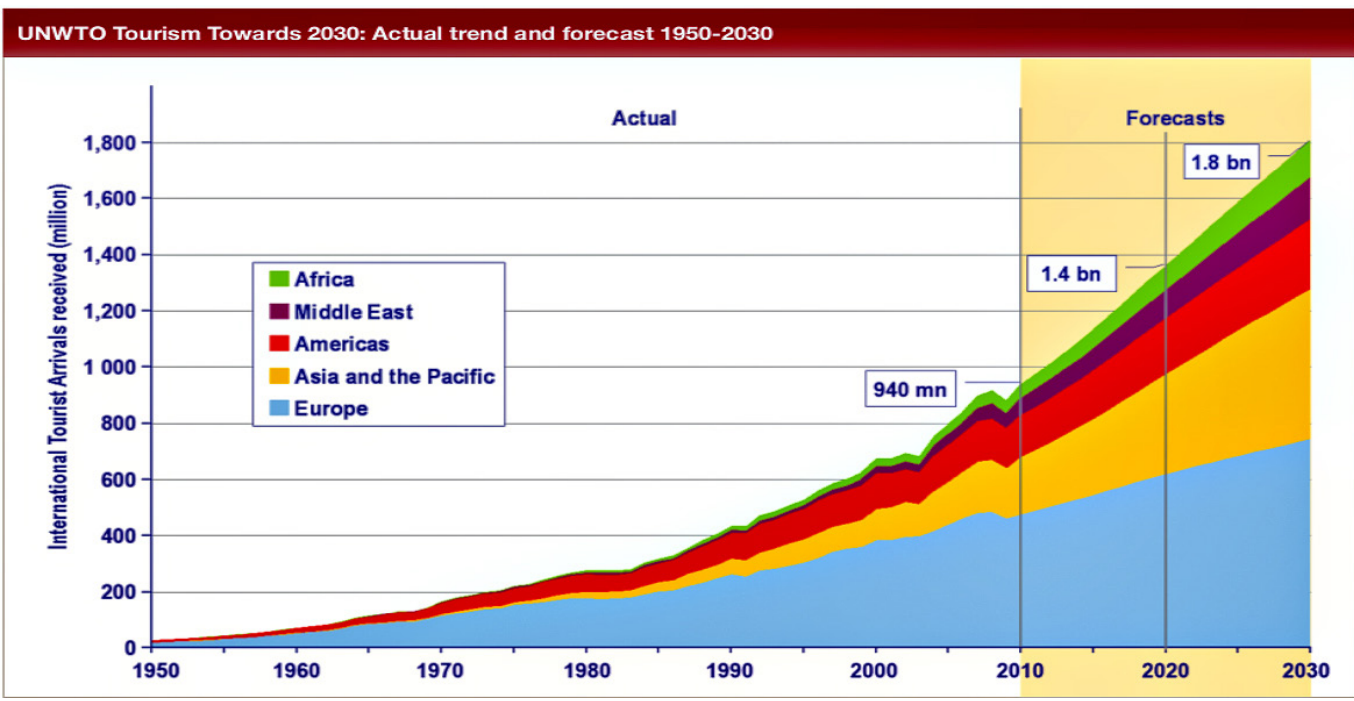

Figure 1. The dynamics of tourist movements since 1950 with predictions until 2030. Source: UNWTO, 2011.

In the period of conquering new markets, franchising and management contracts represent the two basic forms of growth and development in the hotel industry. Chen and Dimou (2005) have explored the main factors influencing the corporate development decision of international hotels with particular reference to franchising versus management contracts. The main results indicate that, although there are similarities between franchising and management contracts, the particular features in terms of controlling hotel operations are strong enough to justify different evaluation and treatment.

Still, the rapid development of hotel chains is facilitated predominantly by the emergence of franchising, as a business model, and megatrends, such as globalization and internationalization. The combination of these factors has led to the top 1o hotel chains in 2016, with 6.125.449 beds in 51.046 hotels around the world, as shown in Table 1.

Table 1. The 10 largest hotel chains in 2016

\begin{tabular}{|l|c|c|}
\hline Hotel chain & Number of hotels & Number of rooms \\
\hline Marriot International & 5952 & 1164668 \\
\hline Hilton Worldwide & 4875 & 796440 \\
\hline IHG (InterContinental Hotels Group) & 5174 & 767135 \\
\hline Wyndham Hotel Group & 8035 & 697607 \\
\hline Shangai Jing Jiang International Hotels Group Co. & 5977 & 602350 \\
\hline Accor & 4144 & 583161 \\
\hline Choice Hotels International & 6514 & 516122 \\
\hline BTG Homeinns Hotels Group & 3402 & 373560 \\
\hline China Lodging Group & 3296 & 331347 \\
\hline Best Western Hotels \& Resorts & 3677 & 293059 \\
\hline
\end{tabular}

Source: Authors according to Hotels'325 (July-August 2017). 


\section{Chronology of IHC arrival to the market of Montenegro}

With the aim of choosing the hotel for primary research, we have analyzed the chronology of the arrival of IHC on the Montenegrin market and certain particularities that indicate their possible influence on tourism industry.

The history of hotel chain business operations in Montenegro compared to other destinations is very short but dynamic. The length of the IHC business in Montenegro is not a measure of their success, but the effects that the hotel chains have had at the hospitality industry in Montenegro and the destination as a whole. The effects of hotel chain operations in Montenegro are numerous and relate to: improving the quality of services in the entire hotel industry, changing the awareness of local hotel operators about the importance of quality management in the hospitality industry and monitoring contemporary market trends, innovation regarding hotel products, improving knowledge and skills of employees in Montenegrin hotels, raising the awareness of the importance of hotel chains concept and the possibilities of applying the modern forms of growth and development of hotel companies and many others.

IHC on the Montenegrin coast have strongly strengthened the demand, thus expressing the secondary elasticity of the demand that encompasses its change as a result of changes made in the tourist offer. Basically, this is a change of demand in which a new offer creates a new demand (Čačić, 2010). Additionally, hotel operators have significantly increased the level of service in hotels, thanks to the arrival of IHC, thus receiving more well-off guests as well as more demanding ones from the aspect of the quality of hotel services.

Furthermore, IHC have brought the number of benefits to Montenegro as a tourist destination from the following aspects: the emergence of new markets in Western Europe, the United States, the Middle East; attracting high-paying tourists and new segments of tourists; promotions to the new markets through IHC sales and marketing channels such as Best Western Hotels and Resorts, Wyndham Hotel Group, Hilton Worldwide and Marriott International.

The chronological overview of IHC entries to the Montenegrin market is given in Table 2.

Table 2. Chronological view of IHC entries to the Montenegrin market

\begin{tabular}{|c|l|c|c|c|}
\hline No. & Brand & $\begin{array}{r}\text { Capacity } \\
\text { (rooms+apartments) }\end{array}$ & Place \\
\hline 1 & lberostar Bellevue Hotel & 566 & Bečići & 2003 \\
\hline 2 & Best Western Premier Hotel Montenegro & 55 & Podgorica & Sveti Stefan \\
\hline 3 & Aman Sveti Stefan & 50 & Podgorica & Tivat \\
\hline 4 & Ramada Hotel Podgorica & 110 & Podgorica & 2012 \\
\hline 5 & Hotel Regent Porto Montenegro & 149 & Podgorica & 2016 \\
\hline 6 & CentreVille Hotel and Experience & 122 & Kolašin & 2016 \\
\hline 7 & Hilton Podgorica Hotel & 69 & 2016 \\
\hline 8 & Four Points by Sheraton Kolašin & & \\
\hline
\end{tabular}

Source: Authors according to the data published on official web sites of hotels

Each of these hotels has its own particular features and its entry to the Montenegrin market had different effects. The basic characteristics and contribution of each individual branded hotel, with the introduction of contemporary trends in the hospitality industry in Montenegro, will be dealt with in the part of the discussion as well as with the results of the research carried out. Hotel Ramada was chosen particularly for the arrival of new management in 2016 
which, by its engagement in regular staff trainings, relations with the local stakeholders and activities for establishment of socially responsible business, indicated that the manner of their operation on the Montenegrin market could have significant impact on the local operators in hospitality industry

\section{Results of research and discussion}

The attitudes of the interviewed top management in selected hotels have confirmed that over the course of the past five years the hospitality industry in Montenegro has experienced a number of changes. The fact that new trends which are largely attributed to international hotel chains became prominent in 2017 was confirmed by all three top managers. Further, the arrival of Hotel Ramada Podgorica to the Montenegrin market in 2012, with its four fully equipped congress halls and total capacity of about 400 seats, strengthens this trend on the market and sets it as a standard offer in Podgorica hotels, as particularly stressed by the manager of Ramada. The others agreed, stressing that the emergence of hotel Best Western Premier Hotel Montenegro in 2006 started congress tourism because until then most of the hotels in Podgorica had no congress halls, but the existing halls were occasionally used for the purposes of congress organization. By opening the Ramada Hotel Podgorica, owned by a company from Turkey, there is an inflow of business guests from this market, and congress tourism is becoming a modern trend on the Montenegrin market. Shortly after the opening of the Ramada hotel, Turkish Airlines opened the Podgorica-Istanbul airport line, as well as a branch in the vicinity of the hotel, thus improving the availability of Podgorica and Montenegro destination in general. According to the sales manager at the Ramada Hotel, congresses and seminars held there will launch the hotel in its entirety and bring all of its sales sectors into a position of revenue generation.

The interviewed managers mention another hotel, with a short run in the market, the Center Ville Hotel, which, like the most hotels in Podgorica, is equipped with congress facilities. Renting the congress capacities brings revenues, but the effects which the event organization has on restaurant and accommodation capacities are considerably higher, argued the sales manager of Ramada Hotel. As he stressed out, for catering industry, the changes made by IHL in the internal environment are equally important. As Dess et al. said (2007), the changes in the internal environment are divided into the changes in the company's value chain and resources. Common denominators for all the changes in the internal environment are the standards. The branded hotels have contributed to familiarize local hotel providers with standards, and to implement them. According to the GM Hotel Ramada, local hoteliers are particularly interested in getting to know the safe standards, communication, standards of behavior and dressing of employees. Based on the information provided during the interview, it is concluded that the hoteliers are interested in these standards since their implementation enables cost reductions and increases efficiency in the business.

The arrival of branded hotels into the Montenegrin market has led to changes in the behavior of major hotel principals, primarily travel agencies. Travel agencies have deepened their relationship with hotels based on the takeover of certain hotel sales activities, such as bidding performances. Top manager of the Hilton Hotel considers that a stronger cooperation between travel agencies and hotels is obvious, providing an example of the Congress Travel agency, which opened a branch at the Hilton Hotel, when needed, it technically serves the hotel's capacities and generates the demand for the same. 
In addition, the expansion of demand for conference facilities led to the opening of specialized travel agencies for congress tourism, which appeared on the market as generators of demand and as hotel suppliers with the equipment to hold conferences at the highest level, as considered by the interviewed managers. Such cooperation is another aspect of outsourcing, but from the aspect of the event management. The event management has contributed to the development of the following specialized agencies for decorating, lighting, wedding ceremony organizations, birthdays and similar, and has opened up a spectrum of new occupations and activities which are the key hotel principals in everyday business, as pointed out by sales director of Ramada.

The key to success of international hotel chains, apart from the brand, is the rationalization of business. Outsourcing is one of the key ways to achieve rationalization in business, as pointed out by managers of hotels Hilton and Ramada, the hotels which use this method of cost rationalization. This kind of partnership between the hotel and travel agencies, according to the manager of the Ramada hotel sales, did not exist in Montenegro until the emergence of IHC.

In order to establish a value chain in Podgorica, the hotel management has initiated the creation of complementary relationship between hotel operators and restaurant owners. The relations between caterers in the market still have not reached the desired level, but the situation is significantly improved from the aspect of mutual cooperation in the case of overbooking and the assignment of an additional inventory. The management is currently working on raising the awareness of the need for joint participation in foreign markets and linking with the local tourist organization of Podgorica.

In addition to the above-mentioned cooperation with tourist agencies, with the introduction of IHC on the market, cooperation with other market principles has been improved, through outsourcing, allowing hoteliers to rationalize their business. This business model was not a practice in Montenegrin hotels until the arrival of IHC. Outsourcing is a practice used by different companies to reduce costs by transferring portions of work to external suppliers rather than completing it internally (Investopedia, 2017). Hotel Ramada has outsourced laundry services, thus achieving higher quality services, with savings in the costs of bills and staff. The hotel has also introduced some modern methods to reduce demand fluctuations, such as special gastronomic offer actions aimed at reducing daily demand fluctuations and low season-related activities. Thus, in 2017 Wyndham launched the "winter promotion" campaign in January and February $-30 \%$ on the price of accommodation at Wyndham hotels. Numerous actions such as "Extended Weekend" for the Valentine's Day, and the March 8, "Ramada Brunch", and others, were initiated by the hotel management.

In order to establish a higher quality of the hotel offer, the management has expanded its range of services. It has introduced transfer services as well as renting bicycles for hotel guests, and through the cooperation with the gym "Soko Gym", gym and spa treatments are provided. This has significantly improved the service package targeted at the business segment.

With the arrival of the new management in October 2016 (Savana Continental Property Management and Lodging), the relationship with the employees has significantly improved, giving importance to the main resource in the hospitality industry, which is the workforce. Every employee in the hotel, in line with his position, was given the opportunity to attend some of the training to improve knowledge, skills and competences in accordance with their interest. In March 2017, a Wyndham group expert held training in the sector of sales and reception, in use of the hotel PMS "Opera". Socially responsible business activity, care of employees and the business environment as well as partnerships in the market are three macro trends that Ram- 
ada implements on the Montenegrin market. Hotel Ramada is implemented in the Wyndham Green program which requires Ramada Hotel Management to work globally and act locally by:

- Developing environmental programs, products and services

- Setting environmental impact targets and measuring performance of green programs

- Working with our associates, suppliers, owners and local communities to minimize our environmental impact

- Complying with climate policies and environmental laws (Wyndhamworldwide, 20062017).

It should be taken into account that the form of growth and development of Hotel Ramada is a franchise. Franchising, since it first appeared as a modern business form in 1863, has immensely changed the way of business in the world (Pine et al., 20oo). Further, brand identification helped franchisees to increase sales and this became the driving force behind the growth of chain hotels in the 1960s and the 1970s (Connell, 1992). It is unimaginable that the Hotel Ramada's location coincides with the familiarity of this brand, allowing it easier communication with consumers, as well as with all the stakeholders at the destination.

Due to the entire contribution of the Hotel Ramada Podgorica, it is concluded that this hotel played a significant role in positioning Podgorica as a tourist destination. The Regent Hotel also had the same role in positioning Porto Montenegro as a destination for luxury tourism. Porto Montenegro with a hotel Regent Porto Montenegro, established new business standards in the area of Tivat, which was reflected in the physical appearance of hotel facilities, as considered by the top manager of Regent. The manager is aware of the fact that tourists see the destination as a whole and therefore states that from the aspect of competitiveness it is good that hotels in the port and in the environment are improved. Over the last three years, two hotels, Pine and Palma, have been renovated, taking a new Mediterranean look and higher quality services, providing them with a higher category of 4 stars $^{3}$. In addition to the renovation of the existing ones, new five-star hotels, such as the La Roche Hotel, were opened. According to the Montenegro Tourism Development Strategy by 2020 (2008), the main emphasis should be on building hotel facilities and similar holiday facilities that meet higher categories criteria.

Hotel Regent along with Porto Montenegro has set new trends and business standards that the micro destination Tivat has accepted completely and is committed to adopting new trends and increasing the quality of services at the destination. Tivat is the first destination in Montenegro where complementary relationships between market participants are being developed and where the synergy of business entities is recognized, as proudly pointed out by the manager of Hotel Regent. They are not just hotels dedicated to the quality of service, the restaurant service in Tivat is at an extremely high level and it is aligned with the demands of tourists staying in high category hotels. Also, shopping offer supports the needs of high-paying tourists. The Regent Hotel has also made contribution to setting standards for gastronomic offer. In order to achieve a high quality gastronomic offer, the hotel is dedicated to cooperate with dominant local suppliers. As the hotel implements the HACCP Food Quality Control System, it is also necessary for suppliers to enter the same, thereby improving the quality of the supply chain business in Montenegro. In this way a high standard of service is achieved, available not only for elite hotels, but also to passengers on yachts which sail to the marina. According to the information obtained in the interview with the Regent Hotel management, a high stand-

3 Previously categorized as a 3-star hotel 
ard of quality established in this manner, has been successfully implemented for two years, to the satisfaction of tourists and suppliers.

With the aim of inspecting the validity of the identified trends, which by the arrival of IHC came to the Montenegrin market, an additional research was carried out for the purpose of the paper. The research was conducted using a telephone interview method and included all branded hotels in Montenegro. Regarding the level of congress tourism development, 5 hotels or $62.5 \%$ of the total number of hotels declared that congress facilities are mandatory part of the hotel product, and $37.5 \%$ think these facilities exist, but do not make the backbone to the hotel business. At a time when the destination has several internationally renowned brands, it is possible to have a better organization of international events, which significantly affects the competitiveness of the destination in relation to destinations in the region. This makes the significance of IHC broader emitting a strong influence not only on hotel industry, but also on the destination as a whole.

When asked about cooperation with tourism agencies, two hotels, Aman and Regent, responded that their focus was on OTA ${ }^{4}$ and direct sales, and six of them (75\%) had good cooperation with tourist agencies and because of the planned growth of charter flights to Montenegro, in the future they expect even more solid cooperation with them.

Interestingly, with respect to outsourcing, only two hotels have opted to use outsourcing, two occasionally use it, when it comes to rental of translation equipment during congresses, while the remaining $50 \%$ have stated not to use this type of service.

When it comes to cooperation with its competitors, 7 hotels $(87.5 \%)$ declined to cooperate with their competitors, while Aman Resort, whose system develops a "closed" business culture, considers its facility and business concept unique and has not identified a company that could support their business model and create complementary relationships with them. The philosophy of the Aman chain is based on peace, silence and separation. Accordingly, the hotel business is rather closed, with no pomp and excessive public communication. Certainly, this prestigious brand has had an impact on the growth of demand for exclusive guests, but the above mentioned isolation in business manifested not only to the principals, but also to the local population and other tourists in view of the poor accessibility of parks and paths and the use of beaches, which, due to the pricing policy, remain affordable only to high-paying clients (Đurašević, 2015). Such business policy has led to the fact that the most effects of tourism are seen within the range of the resort, therefore the local population suffers. This hotel mostly contributed to the destination by giving promotion of Montenegro, which indirectly influences the attractiveness of new investments.

When it comes to quality standards and quality services, all eight hotels hold the attitude that they are constantly working to establish a quality standard. While Regent implements the HACCP Food Quality Control System, Hotel Center Ville applies HACCP and HALAL.

Answers regarding the question of whether PMS and CRS are used are rather interesting. Seven hotels (87.5) voted for the use of CRS, all except the Center Ville, which are the only ones, with Regent, who use PMS. It is characteristic for Regent to improve the existing PMS and develop it in accordance with its needs, especially in terms of cost rationalization. It should be noted that most of the branded hotels in Montenegro do not use PMS as a platform to manage front-office capabilities, such as booking reservations, guest check-in/check-out, room assignment, managing room rates and billing surprisingly, and it can be argued that hotels use different operating systems at a lower level of coverage than PMS.

4 Online Travel Agency 
Care is taken of the employees, except that the Best Western hotel does not have a developed program, but this issue deals with management's assessment. According to the operation manager of the Hilton Hotel, all employees have undergone initial training for their positions, but the management of the hotel is aware that employees' performance needs to be raised to a higher level. Since the period from the opening of the hotel to the present day has been fulfilled by other priorities related to the positioning of the hotel on the market, additional staff training is an activity that is expected to be carried out in the future.

Three hotels (37.5\%) deal with the care for the environment, while others have argued that there is no formal program of environmental protection, but only guidance for guests.

Two hotels are actively engaged in socially responsible businesses and the remaining 6 (75\%) do not have this item in their program. As noted above, Hotel Ramada has developed programs of care for employees, the environment and socially responsible business.

Table 3 shows the attitudes of IHC management in Montenegro regarding the identified modern trends in hotel industry.

Table 3. Frequencies of IHC attitudes on identified modern trends in hotel industry in Montenegro

\begin{tabular}{|c|c|c|c|c|c|c|c|c|c|}
\hline Offered answers - TRENDS & BW & Aman & IberoS & Sheraton & Hilton & Ramada & $\begin{array}{c}\text { Centre } \\
\text { Ville }\end{array}$ & Regent & $\begin{array}{c}\% \text { of } \\
\text { frequency }\end{array}$ \\
\hline Congress facilities & $x$ & & & $x$ & $x$ & $x$ & $x$ & & 62.5 \\
\hline $\begin{array}{l}\text { Cooperation with tourist } \\
\text { agencies }\end{array}$ & $x$ & & $x$ & $x$ & $x$ & $x$ & $x$ & & 75 \\
\hline Outsourcing & & & & & $x$ & $x$ & & & 25 \\
\hline $\begin{array}{l}\text { Collaboration with } \\
\text { competitors }\end{array}$ & $x$ & & $x$ & $x$ & $x$ & $x$ & $x$ & $x$ & 87.5 \\
\hline Quality standards & $x$ & $x$ & $x$ & $x$ & $x$ & $x$ & $x$ & $x$ & 100 \\
\hline PMS & & & & & & $x$ & $x$ & $x$ & 37.5 \\
\hline Care of employees & & $x$ & $x$ & $x$ & $x$ & $x$ & $x$ & $x$ & 87.5 \\
\hline Care for environment & & $x$ & & & $x$ & $x$ & & & 37.5 \\
\hline Socially responsible business & & & & & & $x$ & & $x$ & 25 \\
\hline
\end{tabular}

Source: Authors according to telephone interview

The table shows that the percentage of quality standards frequency by the attitudes of hotel managers interviewed is the highest and is $100 \%$. They are followed by cooperation with competitors and care for employees with $87.5 \%$ rate, cooperation with tourist agencies $(75 \%)$ and development of congress tourism (62.5\%). The lowest frequency was observed in the application of outsourcing trends and socially responsible business $(25 \%)$. It is necessary to note that in answers to open questions regarding "congress facilities" the respondents from hotels Aman and Iberostar stated that they do exist, but they do not make a backbone to the hotel business, and in Regent they told that they are not a compulsory part of the hotel product, which was positively stated by $62.5 \%$ of respondent managers. It should be noted that Ramada Hotel was the first to initiate creation of the conditions for development of congress tourism, which by its own example was followed by Best Western and Hilton. Similar thing occurred with the category "tighter cooperation with tourist agencies", in hotels Best Western, Aman, Hilton and Regent, where managers stated that it existed, but the focus was on OTA and direct sales. Through franchise system of Ramada hotel, the sales and marketing of the hotel are supported by the Wyndham Hotel chain, which is listed among top five largest franchise hotel chains worldwide, enabling the hotel Ramada access to numerous worldwide markets. The initially 
organized groups from China, Israel, Japan, Canada, and other countries visited Montenegro thanks to corporative hotel sales of this very brand. Additional questions in phone interviews related to "using of sophisticated PMSs", state that nearly all branded hotels in Montenegro use CRS (except for Centre Ville), and that merely $37.5 \%$ of them apply PMSs, with Regent being the most efficient, improving the existing PMSs according to the needs. When it comes to application of "outsourcing" services with branded hotels in Montenegro, the research shows that it goes rather slowly, and in this case as well the Ramada Hotel holds the initial position, which in the former practice used outsourcing on several occasions in order to optimize the business.

From the obtained results it is concluded that international hotel chains in Montenegro apply most of the contemporary trends that have been explored. Accordingly, through cooperation with tourist agencies, other stakeholders, destination competitors, the application of quality standards, care for employees and the environment, socially responsible business and through the implementation of CRS and PMS, undoubtedly make an impact on the operation of hoteliers at the destination. Further, the table shows that Ramada Hotel Management had a positive answer to all the questions (see the part research results and discussion), which is another reason for the focus being at this hotel.

\section{Conclusion}

Hospitality industry in Montenegro has undergone a series of changes over the last five years. Although the share of branded hotels is small, the power inside makes them dominant on the market and allows them the position of the demand generator and partly the creator of the offer.

Montenegro as a destination with the introduction of branded hotels on the market has experienced numerous direct and indirect benefits of their business. Directly-branded hotels have set new business standards, exerting an impact on the quality of service in the catering sector, thereby contributing to the creation of higher quality offer throughout the destination. Indirectly, they are worthy of intensifying foreign investments, increasing the quality of services of the main market principals and all participants in the creation of tourist offer of Montenegro. The research has shown that the contemporary trends set up by branded hotels: congress facilities, cooperation with tourist agencies, outsourcing, collaboration with stakeholders from the destination, implementation of safety standards, using CRSs and PMSs, care for employees and environment, caring for socially responsible business, coincide with the trends applied at the Ramada Hotel.

Some of these trends, such as the trend of introducing congress capacities, cooperation with tourist agencies and different competitors, the use of sophisticated software, have already been fully implemented in the hospitality industry, while the other trends are currently at the level of raising awareness about the importance of their implementation. Since the hospitality industry in Montenegro has been rapidly changing over the last ten years, and the awareness of the necessity for changing and adopting new trends is at a high level, it is expected that the implementation of all these trends will take place within the period of 5 years.

Among the branded hotels present in Montenegro, Ramada Hotel, from the aspect of its influence on the market as a whole, a significant number of accommodation units and having certain specifics in business, proved to be the hotel that exerts the greatest impact on the hotel industry, enabling it to be a generator of new trends in modern hotel business of Montene- 
gro. As a well-established city hotel, Ramada Podgorica works closely with the Local Tourism Organization and the National Tourism Organization, thus making a strong impact not only on hotel industry, but increasing the possibility of developing Podgorica as a tourist destination as well. Last but not least, the elaborated example of the Ramada Hotel Podgorica shows the advantages of popular franchise agreement in the time of internationalization for successful business and the importance for the local market.

\section{Acknowledgment}

This research was supported by Savana Continental Property Management and Lodging and Thomas Management Company. We thank our colleagues Ivana Đurović and Thomas Pavlović who provided insight and expertise that greatly assisted the research. Many thanks for their comments which significantly improved the paper.

\section{References}

Čačić, K. 2010. Business of hotel companies, Belgrade: University Singidunum. (in Serbian)

Dess, G., Lumpkin, G., Eisner, A. 2007. Strategic Management, Belgrade: Data Status. (in Serbian)

Lockwood, A., Medlik, S. 2001. Tourism and Hospitality in the 21st Century, Oxford: Butterworth-Heinemann.

McCarthy, E. J. 1975. Basic Marketing. 5th Edition, Homewood/III

Mussnig, W. 2007. Strategien Entwickeln und Umsetzen. 1st Edition, Wien: Linde Verlag

Porter, M. 2008. On Competition; 11th Edition; Boston: Harvard Business Press.

Alon, I., Ni, L., Wang, Y. 2012. Examining the determinants of hotel chain expansion through international franchising. International Journal of Hospitality Management 31, 379-386.

Barjaktarović, D., Pindžo, R. 2016. Contemporary trends in the hotel industry development. Turističko poslovanje 18, 5-16.

Chen, J.J., Dimou, I. 2005. Expansion strategy of international hotel firms. Journal of Business Research 58, 1730-1740.

Connell, J. 1992. Branding Hotel Portfolios. International Journal of Contemporary Hospitality Management 4. (1), 26-32.

Djurasevic, S. 2015. Aman Sveti Stefan Resort: a challenge for destination management, SITCON, Book of proceedings, Singidunum University International Scientific Conference, 18-22. http://portal.sitcon.singidunum.ac.rs/Media/files/2015/Sitcon-2015.pdf

Pine, R., Zhang, H. Q., Qi, P. 20oo. The challenges and opportunities of franchising in China's hotel industry. International Journal of Contemporary Hospitality Management 12 (5), 300-307.

Collins Dictionary, 2017. https://www.collinsdictionary.com/dictionary/english/trend, connection 16.08.2017.

ETOA (The European Tour Oprators Association). http://www.etoa.org/media/all-news/newsitem/fast-forward-to-2017-what-will-the-global-hotel-industry-look-like-HT

Special Report Hotels 325, The Winds of Changes, taken from www.hotelsmag.com, http:// www.marketingandtechnology.com/repository/webFeatures/HOTELS/h1607_Special_ Report.pdf, connection 13.08.2017. 


\author{
\|\|$\|$ \\ Internet 1: www.aman.com/resorts/aman-sveti-stefan (20.12.2017.) \\ Internet 2: www.bestwestern.com/en_US/book/hotels-in-podgorica/best-western-premier- \\ Internet 3: montenegro/propertyCode.89802.html (20.12.2017.) \\ Internet 4: www.cv-hotel.com/ (20.12.2017.) \\ Internet 5: www.fourpointskolasin.com/ (20.12.2017.) \\ Internet 6: www.iberostar.com/en/hotels/budva/iberostar-bellevue (20.12.2017.) \\ Internet 7: www.investopedia.com/terms/o/outsourcing.asp (17.08.2017.) \\ Internet 8: www3.hilton.com/en/hotels/montenegro/hilton-podgorica-crna-gora-TGDPMHI/ \\ index.html (20.12.2017.) \\ Internet 9: www.mrt.gov.me/biblioteka/izvjestaji, (17.08.2017.) \\ Internet 10: media.unwto.org/sites/all/files/pdf/unwto_2030_ga_2011_korea.pdf (10.08.2017.) \\ Internet 11: www.ramadapodgorica.me (20.12.2017.) \\ Internet 12: http://www.regenthotels.com/regent-portomontenegro/accommodation \\ (20.12.2017.) \\ Internet 13: www.wyndhamworldwide.com/category/about-wyndham-green (17.08.2017.)
}

